\title{
JOURNALIST PUBLIC WORK IN US UNIVERSITIES
}

\author{
Khrystyna Martsikhiv \\ Post-graduate student, \\ Lviv Politechnic National University, Lviv, Ukraine \\ ORCID: 0000-0003-4637-6604, e-mail: khrystyna.r.martsikhiv@lpnu.ua
}

The article deals with the application of public activity method on the example of professional training of journalists in US universities. The implementation of journalist public work into curricula has been characterized.

The research provides factors that influence the successful integration of journalist public work in the learning process. The difficulties of student public work implementation in the learning process as well as positive results of this method application in practice have been analysed. It is defined that the method of public work promotes the development of leadership, personal and social qualities among journalist students.

Based on constructivist paradigm the service-based and collaborative approaches in journalism studying have been analysed. The article also describes how service learning from the point of constructivist approach can facilitate interactive method of journalist studying. The benefits of experiential learning in journalist educational process have been outlined. Three domains of experiential learning have been identified: cognitive or mental skills; affective or emotional areas; manual or physical skills. It is noted that each domain has series of categories that reflect the level and type of learning. It is stated that each category represents $a$ hierarchy moving from passive learning to active and points out the role of experiences in journalist studying.

The article highlights the modes which experiential learning is based on: receptive mode that consists of shooting video, recording speeches by journalists; analytical mode is focused on developing critical thinking of journalists; productive mode is concentrated on accomplishing difficult tasks and journalist adapting to challenging situations; development mode consists of acquiring competence and mastery in professional sphere; psychological mode deals with personal and social growth of journalists. The prospects of further research in this area have been revealed.

Key words: USA, university system, journalism, professional journalist, professional training, curriculum, teaching methods, public sphere pedagogy, civic education, public work

Розглянуто застосуВання методу громадської діяльності студентіВ на прикладі професійної підготовки журналістів в університетах США. Охарактеризовано особливості Впровадження громадської діяльності студентівжурналістіВ в освітні програми. Виокремлено фактори, які впливають на 
успішну інтеграцію громадської діялності майбутніх фахівиів журналістів у навчальні плани. Проаналізовано труднощі впровадження громадської діяльності у навчальний процес журналістів у закладах вищої осВіти США, а також позитивні результати застосування цъого методу на практиці. Визначено, що метод громадської діяльності сприяе формуванню у студентівжурналістіВ лідерських, особистісних та громадських якостей. Виявлено перспективи подальших дослідженъ у иій сфері.

Киючові слова: США, університетська система, фахівець-журналіст, журналістика, професійна підготовка, навчальна програма, методи навчання, громадська педагогіка, громадське виховання, громадська діяльність

\section{Introduction}

Nowadays, the system of civic education in Ukraine is considered to be on the reformation stage. According to the «National Doctrine of Ukrainian education development of the $21^{\text {st }}$ century» the main priority of governmental policy is to find conditions for personal development of each citizen, upbringing journalists who will support democracy, follow civic rights and freedom, treat other national traditions, culture, religion in the respectful way. This situation stipulates the necessity of modernizing system of professional journalist training by adopting positive experience of other countries, especially USA, whose universities propose curriculum for journalists on a high level. It is stated that studying journalism of Ukraine is theoretically based but journalists require practice-oriented training. Applying of active methods of studying by integrating public work as an integral part of journalism curriculum with the aim of helping community and forming public student awareness is widely used in the process of journalist training in USA. This practice is determined to be a good mode for optimizing professional journalist training in the higher educational system of Ukraine.

The issues of civic education are the object of such modern scientists as L. Amanbayeva, O. Bazhanovska, N. Vokhmina, N. Holubkova, and M. Jacobson etc. Comparative historical analysis of theory and practice of civic education has been examined by Z. Malookoi, M. Jacobson. The role of youth public organizations in the USA and Ukraine has been defined in works of N. Vokhmina and N. Holybkova. The service-learning of journalist studying in US universities has been considered by R. Brent, L. Britt, T. Crews, R. Felder, A. North and others.

The purpose of this article is to carry out pedagogic research by integrating student public work in curriculum of journalist studying process in US universities. The purpose will be reached by implementing such tasks: to analyse the structure and content of journalist curriculum in the USA; to examine peculiarities of journalist public work and its possibilities of integration in curriculum; to investigate the influence of applying this active method to journalist studying process.

Analysing journalism curriculum in American universities we can say that one of active methods is the experiential learning. It is defined as an educational process during which a student experiences an event, acquires competencies and knowledge in different environments. There is an increasing tendency of introducing various 
options of extracurricular activities in journalist work such as student involvement in conferences, seminars and workshops, attending social events by providing extensive coverage via blogs and other social media tools [9]. It is necessary to outline specific modes of experiential learning in journalist educational process such as receptive, analytical, productive, development and psychosocial proposed by scientists Gibbons and Hophinks.

The receptive consists of two states: simulated and spectator. Simulated state is based on journalist involvement in virtual environment. This phase can be introduced when journalist students get acquainted with the event via investigating the website and analyzing the programming. The event choses programming via innovative online system where panelists give their offers, and the community votes for them. Journalists who are going to participate in this project provide questions, simulate the experience through the experiences of others, watch videos of past speakers to obtain new knowledge and feel the atmosphere of conference. The spectator aspect is built on student engagement in multimedia reporting and gives them opportunities to gain practical skills in communication with the help of various methods.

Analytical mode is considered to be one of the most significant in journalist studying. Students are engaged in discovering media environment and are required to write a blog on the topic which is interesting, analyze past posts and make recommendations for the current project. During working on the project journalists are divided into three groups. The main group is responsible for the content and makes sure whether the coverage is complete. Another group of journalists is in charge of all social media aspects of the project, publicizing the project and new content announcement. The third group has responsibilities for working on the project appearance on the Word-Press site and giving some recommendations or additions concerning the project functionality. This mode improves student analytical skills and competency. Journalists are expected to produce and post content, shoot and edit video [8].

Productive mode of journalist studying is focused on getting a wide range of skills including taking photos and shooting video. Students conduct interviews either in person or via Skype and get interesting and visual content on the site. In many cases journalists face up with asking tricky questions during interviews. After the interview students are going to provide reports from each team and discuss some challenges, issues etc. During these project execution journalists are encouraged to find new ways to cover the event, visually represent the conference which includes interviews with panelists or attendees.

Development mode is related to journalist competence and mastery. The competence aspect starts with previous courses students have taken in and where they learn and practice multimedia skills. Mastery phase occurs when journalist students feel confident in applying equipment and software so they can be more productive in making their posts.

Psychosocial mode is connected with personal and social growth of journalists. Students get long-term benefits which are sometimes difficult to assess directly after the event. Analyzing personal growth, we can note the fact that journalist student receives a level of comfort while interviewing people and networking with 
outstanding technology leaders. This experience will provide a basis for future networking where students can share their ideas and observations of current technology. The final and the most significant aspect of the project is social growth during which journalists are expected to integrate into technology and media community [8].

Having researched modes of journalist studying, we can conclude that all modes give a good chance for students to do real-time reporting and propose integration into event, better understanding of producing media and excellent opportunity to network with professional journalists. Moreover, students deal with a professional language and dynamic integrated media and technology environment.

It is important to note that journalists' civic education or service-learning in US universities is one of the forms of experiential education and is directed to acquire civic knowledge, skills and personal qualities which are considered to be crucial for living in a democratic society. To begin with, the civic education can be realized by introducing the course of social and political studies, history into journalist curriculum etc. However, such scholars as J. Salmarsh and E. Zlotkovsky outline the fact that learning these subjects will be not enough to promote public work of journalists. They suggest student involvement in various community organizations by getting more practice [12].

Initially, it is necessary to define the term service-learning. There are various definitions of service-learning that distinguish it from other forms of experiential education. Thus, service-learning is based on enhancing academic learning, transforming theory into practice and ideas into actions, helping students to participate in creating democratic society. Moreover, service-learning promotes student understanding of individual leadership and social responsibility in the local, national and global multicultural society. Service learning can be incorporated in curriculum as optional course, additional credit attached to an existing course or integrated into program requirements [1].

Taking into consideration information above, we can state that journalist education in the USA is facing convergence which requires highly marketable graduates who need to present professional competencies and perform tasks in multiple platforms. These goals can be reached by service learning which will help journalists to develop critical thinking skills and understanding of social issues and human inequality; improve writing, communicative skills while speaking with public [3]

It is significant to prove that survey done by Society of America's Educators Academy indicates that nearly $75 \%$ of American establishment use service-learning in the classroom and other higher institutions reach service-learning online. American universities help journalism students to improve their skills in public work via university-based PR agencies. For instance, newsroom in Temple University's Multimedia Urban Reporting Lab proposes students hands-on experience in print, broadcast and Web media. University of California-Berkeley and City University of New York engage students in hyperlocal reporting [11]. Media School in Indiana University in Bloomington also proposes service-learning for journalism students. It is important to say that the service-learning class in Media School is focused on student interaction with organizations and people in community. During classes students can 
solve different problems and troubleshoot production issues. We can also point out that service-learning for journalism students consists in serving as volunteers at local non-profit or other organizations. In Bloomington University students are supposed to be involved in project-based service-learning, working directly with people on special projects where they present their skills. Journalism students in Media School have also great opportunities to attend service-learning classes in: "Video Storytelling», «Studio Production», «Radio Innovation», «Experiments with the Film Camera» etc. Journalism students during the semester in Studio Production can create and produce public service announcements and volunteer recruitment videos for non-profit organizations (Indiana University Bloomington).

Indeed, experiential learning can be behavioral, action-based, cognitive or social. All of them happen simultaneously, since the experience itself has many dimensions. Gentry formulate experiential learning as progress from «low experiential learning potential» to «high experiential learning potential» by experiencing real world situations. The scientist confirms that this real experience leads to learning but only under right conditions [7]. American Presidential Election 2012 is viewed to be one of the best examples of journalist experiential learning. Approximately three hundred journalist students from undergraduate and graduate courses were involved in this project. Students were divided into multimedia team in order to create real converged newsroom. Editorial and leadership roles were devolved and students by themselves decided which aspect of election to cover and how. Journalists held editorial meetings and had complete freedom to decide which issues they considered of most importance. Students also had a chance to respond to one-the-day events in different campaigns, produce multimedia features on some key issues. Journalists worked individually feeling completely independent as well as in groups feeling the spirit of team. They constructed multimedia graphics to explain how the US electoral system works and investigated people from all sides of political division. According to information mentioned above, we can point out that US 2012 gave a lot of opportunities for journalist learners: it engaged students in real and important event; there was a real audience; students had to respond to breaking news, election programs were longer and different in style; students worked with peers from other disciplines; the coverage was rolling; students had a shift work which reflects the reality of professional journalism; they had decision-making authority and opportunity for real live reporting; journalists acted outside of their comfort zone in extreme conditions; they had a chance to write blogs on a real time event and there were more technical opportunities. Analyzing all these activities and opportunities provided for journalists, it is concluded that they prove Gentry's pedagogic model and created an experiential environment for journalist students who were successful at working due to tight deadlines, creating stories and presenting writing and production skills. During this project they got more practice and were able to learn more than in the classroom. This experience should be recognized as a prominent factor in journalist experiential learning [2].

Having done the research of journalism curriculum in US universities, we can outline that service-learning is based on constructivist approach which is oriented on student ownership encouragement and self-awareness in learning process. In 
contrast to a traditional classroom, in a constructivist setting journalist learners take a responsibility for their learning environment. Taking into account the principles of education, the researchers outlined that constructivist approach in journalism service-learning assists students to transform, share and re-create information and prepare them for self-directed work. Without any doubts, we can remark that decision-making, collaborative learning and independent projects are significant in journalist service-learning process [5].

Collaborative journalism learning confirms that students learn with and from people who surround them. They can accept challenges by working together on projects such as development of kindergarten guide for their community. Thus, it means that journalism student take responsibility in making decisions. The methods that require students to independently solve problems belong to the case study which is applied at the University of Pennsylvania, while studying the discipline «Media Ethics» at Emerson College, University of Wisconsin - Madison, National University, and University of South Florida etc. The professional activity of a journalist is connected with the search for information that is why he often has to conduct independent journalistic investigations and experiments. Journalist students learn not only to make independent decisions in difficult situations, but also acquire skills through examples from professional public work. We can state that these methods aim at developing journalist creative thinking and cognitive activity, educating future specialists to understand and solve the problem, to put forward a hypothesis and draw conclusions. The main purpose of the case method is to put the journalist student in a situation in which he must find the solution to a given problem. This method improves the skills of journalists in working with information sources, namely the ability to correctly formulate questions and answers, analyse and synthesize arguments, listen and understand others.

To successfully apply the case method, it is necessary to choose a material that would reflect the problem that a journalist may encounter in his professional public work. Another important condition for using this method based on providing a situation which will contain several solutions that will show the complexity of professional activity and must adapt to the knowledge that students need to activate. Thus, in the process of solving the proposed problem, journalists learn to collect process and evaluate information [4].

Analysing journalist curriculum in US higher establishments, it is significant to point out that independent project is determined to be one of crucial part of service learning. In the process of implementing capstone projects journalism students develop the skills in critical thinking, detailed analysis and creative solutions to the problem. For example, at the National University at the Department of Professional Studies journalism students work on a diploma project that is focused on: writing news; collection of material for the reporting; program video recording that covers public issues; conducting interviews; meeting with publishers. As a result of this project, students improve their skills in effective communicating with community members, using media principles, demonstrating the ability to work independently, gathering information quickly, adapting to the news environment, showing flexibility and patience [10]. 
Having examined the service-learning in journalism curriculum, we can assert that it can be successfully carried out in three phases: appraise, extend and evaluate. The first stage of constructivist service-based learning is appraising which lies in journalism student assessment. Service-learning outlines the significance for students to find out the skills that they already have and ways of achieving their goals in professional growth. The purpose of the second stage is to help students to clarify and apply their knowledge in real experience. During this stage teachers motivate and encourage students to apply their practical skills while writing articles for magazines, journals, and blogs. Furthermore, collaboration with peers, community and teachers is a considerable point in journalism studying. Journalism students benefit from collaborating with non-profit organizations, listening to community speakers etc. Teachers have to emphasize on journalism using associated press style, fact checking, and appropriate feature story structure. Journalists covering community events will promote their development of relationships with local residents and cultivation of online community. In the final stage students actively participate in evaluation the products done by their peers. This evaluation permits journalists to analyse their contributions to the whole projects, pointing out peers' strong and weak sides.

\section{Conclusions}

To sum up, it is necessary to outline that despite difficulties that students and teachers face up with introducing methods of public work in journalism curriculum there are several benefits: development of active journalist public position; improvement of critical thinking and skills in real problem solving; development of personal and collaborative values; opportunities to acquire new experience in real public work. All of these journalist activities will help them to understand better changes that can occur in the society and feel own responsibility for their position and work.

The research outcomes state positive impact of applying the method of service-learning in the process of journalist professional training. Despite the fact of widely use of this method in US universities, involvement of student in public or community work has not reached a sufficient level in native scientists' research and requires further implementation in Ukrainian higher education.

Wide spectrum of form and methods of experiential learning with elements of journalist civic engagement in US higher establishments is found to be useful in the process of looking for new technologies and forming civic qualities of Ukrainian youth.

\section{References:}

1. American University Community Center. Available at: http://www.american.edu/ocl/volunteer/Commu nity-Based-Learning-and-Research.cfm.

2. Beard, C., Wilson, J. (2013). Experiential Learning: A handbook for education, training and coaching. London: Kogan Page, 17-29.

3. Britt, L. (2012).Why we use service-learning: A report outlining a typology of three approaches to this form of communication pedagogy. Communication Education, 61(1), 80-88. DOI: 10.1080/03634523. 2011.632017.

4. $\quad$ Communication Research trends (2007). Teaching journalism, 26 (2), 10-12.

5. Dewey, J. (2007). Experience and education. New York: Free Press, 17-23. 
6. Indiana University Bloomington. Available at: http://mediaschool.indiana.edu/news/service-learningclasses-take-students-into-community-for-immersive-experiences.

7. Gentry, J. W. (1990). What is experiential learning? In Guide to Business Gaming and Experiential Learning, Gentry, J. W. (Ed.). East Brunswick/London: Nichols Publishing, 9-21.

8. Gibbons, M., Hopkins, D. (1980).How experiential is your experienced based program? The journal of Experiential Education, 3(1), 32-37.

9. Knight Foundation (2013). The teaching hospital: A goal for journalism education. Available at: http://www.knightfoundation.org/press-room/speech/teaching-hospital-goal-journalism-education.

10. National University. Journalism, Film and Entertainment Acts. Available at: https://www.nu.edu/ OurPrograms/School-of-Professional-Studies/Journalism-Film-and-Entertainment-Arts.html.

11. Pomoni, C. (2009). What is collaborative journalism? Retrieved August 14, 2010. Available at: http:// christinapomoni.wordpress.com/2009/10/20/what-is-collaborative-journalism.

12. Saltmarsh, J., Zlotkovsky, E. (2011) Higher Education and Democracy: Essays on Service-learning and Civic Engagement, Philadelphia: Temple University Press, 3-11.

Received: March, 22

Accepted: April, 23 